\author{
S.I. Riabyi \\ Department of Patient Care and Higher Nursing Education (head-prof. I.A. Plesh) HSEI of Ukraine \\ «Bukovinian State Medical University», Chernivtsi
}

\title{
THE SIGNIFICANCE OF PROTEOLYTIC ACTIVITY OF INTESTINAL WALL TISSUES FOR THE SUTURED AREA HEALING UNDER THE CONDITIONS OF ANASTOMOTIC LEAKAGE DEVELOPMENT
}

\section{ЗНАЧЕННЯ ПРОТЕОЛІТИЧНОЇ АКТИВНОСТІ ТКАНИН КИШКОВОЇ СТІНКИ ДЛЯ ЗАГО- ЄННЯ ЗОНИ З'ЄДНАННЯ ЗА УМОВ РОЗВИТКУ НЕСПРОМОЖНОСТІ АНАСТОМОЗІВ}

Резюме. Мета дослідження - вивчити вплив специфічних змін протеолітичної та фібринолітичної активностей тканин кишки безпосередньо в ділянці з'єднання на регенераторні властивості анастомозів за умов розвитку їх неспроможності. Методи. На моделі неспроможності кишкових швів у 72 експериментальних тварин досліджено зміни показників протеолізу, сумарної, неферментативної та ферментативної фібринолітичної активності з'єднаних тканин кишок. Результати. Встановлено, що підвищена фібринолітична та протеолітична активність тканин кишок може бути одним із механізмів порушення первинної (біологічної) герметичності лінії швів у ранні терміни (12-24 год.). У пізніші терміни (24-72 год.) надмірна активація ферментативного фібринолізу та деградації колагену поєднувалась 3 гістологічними ознаками надмірної нейтрофільної та плазмоцитарної інфільтрації, венозного повнокрів'я та крововиливів, що поширювалися на всі шари кишкової стінки. Така комбінація зростання деструктивних процесів з виснаженням систем захисту може бути в основі порушення регенерації зони з‘єднання 3 виникненням неспроможності швів.

Ключові слова: протеоліз; фібриноліз; регенерація; неспроможність кишкових швів; експеримент.

Despite the reduction of share of full-size operations in abdominal surgery, intestinal sutures insufficiency (ISI) continues to be quite serious complications after operations on the hollow digestive organs. The frequency of the onset of ISI is variable with range 3,8$8,1 \%$ and depends of type of surgery according urgency, region of digestive tract and technical conditions of intervention $[1,2]$. The mortality rate after formation of colorectal anastomosis is up to $22 \%$ [3]. The unsatisfactory results of treatment of this polyethiological complication are largely associated with an insufficient study of all its pathogenetic aspects [4]. In existent researches a great attention deals to study and modification the risk factors of anastomotic leakage, such as nutrition disturbances, smoking, steroids and chemotherapy, duration of surgical treatment, volume of infusion and blood transfusion etc $[5,6]$. It has been proved a significant influence of tissues ischemia, kind of suture material and technical approach on process of healing the intestinal anastomosis [7]. Success of the last one provides by supporting of conditions to optimal regeneration of sutured tissues. It is known [8] that primary biological leak-resistance of sutures on the hollow digestive organs is provided by the formation of fibrin on the se- rous membranes at the place of their connection. Furthermore, the tissue fibrin network is a matrix for fibroblasts that stimulates their growth and synthesis of the collagenous fibers, contributing to an optimal healing of the suture line [9]. Blood supply, bacterial contamination and adequate load of suture line make a significant influence on regeneration of sutured tissues of intestine [7]. Speed of regeneration depends on the processes of formation and destruction of the connective tissue controlled by the activity of the proteolytic, fibrinolytic, pro- and antioxidant systems. Individual papers are partially devoted to a study of the some biochemical processes in the tissue of the hollow organs of digestion [3, 7]. These investigations contain scattered data mainly about changes of biochemical processes in the serum of venous blood in case of ISI. Based of these data it is impossible to make convincing conclusions about of the essence of the changes that occur in site of connected tissues. Thus, a state of fibrinolytic and proteolytic activities in tissues of the intestine directly in the region of applied sutures in case of anastomotic leakage remains obscure.

Purpose of the research: to study influence of specific changes of proteolytic and fibrinolytic ac- 
tiveities of intestinal tissues directly into the region of sutures on regenerative properties of anastomosis under experimental conditions of their leakage development.

Material and methods. The experiments have been carried out on 72 albino nonlinear male rats, weighting $180 \pm 20 \mathrm{~g}$. All the animals underwent a resection of the cupula of the cecum with suturing defect of intestine by means of interrupted stitches (marylon 5-0). ISI was modelled by way of excessive mobilization of the area of junction and a rare application of stitches in the animals of the experimental group. In 12, 24, 48, 72 hours and 5 days following a surgical interference an euthanasia of the animals was performed under anesthesia and the samples of the intestinal tissue in the region of sutures were taken for specific tests. The levels of proteolytic activity by the lysis of: azoalbumin (AA), azocollagen (ACg), azocasein $(A C s)$ and the indices of fibrinolitic activity: total (TFA), nonenzymatic (NFA), enzymatic (EFA) have been researched. Evaluation of reparative processes of the intestinal wall was performed during microscopy of the histological sections of the sutured zone, stained by hematoxylin-eosin, Van Gison, and Slinchenko methods. The Statistical pro-cessing of the investigation results was performed on $P C$ by means of the application "Primer of biostatistics (Primer of Biostatistics, 4th Edition, S.A.Glantz, McGraw-Hill). Data from the groups were compared using MannWhitney's t-test. To reject the null hypothesis the significance level was used equal to $p<0,05$. The experiments were carried out with the observance of the requirements of the European convention as to the protection of vertebrate animals that are used for experimental and other scientific purposes (Strasbourg, 1986).

Results of the research and their discussion. According to the obtained data a reliable steady activation of tissues proteolysis have been revealed in the animals of the experimental group in comparison with the control one (table 1).

So, in 12-24 h. following the operation a reliably higher activity of lysis of AA, ACs and $\mathrm{ACg}$ was detected in the animals of the experimental group $(p<0,001)$. It's testify about increase of proteolytic modification of the low- and high-molecular proteins. In particular, the activity of ACg lysis in the animals of the trial series exceeded twice the control findings which indicates a deeper degradation of collagen molecules in investigated tissues. Increased proteolytic

Indices of proteolytic activity of the tissues of the rat cecum in the anastomotic region

\begin{tabular}{|c|c|c|c|c|c|c|c|c|c|}
\hline \multirow{2}{*}{ Indices } & \multirow{2}{*}{ Intact } & \multicolumn{2}{|c|}{12 hours } & \multicolumn{2}{|c|}{24 hours } & \multicolumn{2}{|c|}{48 hours } & \multicolumn{2}{|c|}{72 hours } \\
\hline & & $\mathrm{C}$ & $\mathrm{E}$ & $\mathrm{C}$ & $\mathrm{E}$ & $\mathrm{C}$ & $E$ & $\mathrm{C}$ & $\mathrm{E}$ \\
\hline $\begin{array}{l}\text { Azoalbumin } \\
\text { lysis } \\
(\mathrm{E} 440 / \mathrm{h} \times \mathrm{g})\end{array}$ & $\begin{array}{c}43,80 \pm \\
1,27\end{array}$ & $\begin{array}{c}56,80 \pm \\
1,19\end{array}$ & $\begin{array}{c}77,76 \pm \\
1,33 \\
* * *\end{array}$ & $\begin{array}{c}74,40 \pm \\
1,73\end{array}$ & $\begin{array}{c} \pm 1,24 \\
* * *\end{array}$ & $\begin{array}{c}83,52 \pm \\
0,86\end{array}$ & $\begin{array}{c}114,04 \\
\pm 1,47 \\
* * *\end{array}$ & $\begin{array}{c}80,08 \pm \\
0,98\end{array}$ & $\begin{array}{c}124,96 \\
\pm 1,84 \\
* * *\end{array}$ \\
\hline $\begin{array}{l}\text { Azocollagen } \\
\text { lysis } \\
(\mathrm{E} 440 / \mathrm{h} \times \mathrm{g})\end{array}$ & $\begin{array}{c}14,68 \pm \\
0,92\end{array}$ & $\begin{array}{c}17,40 \pm \\
1,296\end{array}$ & $\begin{array}{c}31,52 \pm \\
1,602 \\
* * *\end{array}$ & $\begin{array}{c}18,04 \pm \\
1,62\end{array}$ & $\begin{array}{l}55,92 \pm \\
1,602 \\
* * *\end{array}$ & $\begin{array}{c}32,84 \pm \\
1,48\end{array}$ & $\begin{array}{c}48,24 \pm \\
1,68 \\
* *\end{array}$ & $\begin{array}{c}23,36 \pm \\
1,36\end{array}$ & $\begin{array}{c}46,88 \pm \\
0,91 \\
* * *\end{array}$ \\
\hline $\begin{array}{l}\text { Azocasein ly- } \\
\text { sis } \\
(\mathrm{E} 440 / \mathrm{h} \times \mathrm{g})\end{array}$ & $\begin{array}{c}56,78 \pm \\
1,45\end{array}$ & $\begin{array}{c}81,84 \pm \\
1,54\end{array}$ & $\begin{array}{c}106,64 \\
\pm 1,401 \\
* * *\end{array}$ & $\begin{array}{c}67,00 \pm \\
1,84\end{array}$ & $\begin{array}{l}120,00 \\
\pm 1,77 \\
* * *\end{array}$ & $\begin{array}{c}103,56 \\
\pm 1,39\end{array}$ & $\begin{array}{c}116,64 \\
\pm 1,97 \\
* *\end{array}$ & $\begin{array}{c}90,20 \pm \\
1,45\end{array}$ & $\begin{array}{c}111,84 \\
\pm 1,19 \\
* * *\end{array}$ \\
\hline
\end{tabular}

Notes: $C$-control; $E$-experiment; $*-P<0,05 ; * *-P<0,01 ; * * *-P<0,001-$ statistical reliable distinctions

Table 2

Indices of fibrinolytic activity of the tissues of the rat cecum in the anastomotic region

\begin{tabular}{|c|c|c|c|c|c|c|c|c|c|}
\hline \multirow{2}{*}{ Indices } & \multirow{2}{*}{ Intact } & \multicolumn{2}{|c|}{12 hours } & \multicolumn{2}{|c|}{24 hours } & \multicolumn{2}{|c|}{48 hours } & \multicolumn{2}{|c|}{72 hours } \\
\hline & & $\mathrm{C}$ & $\mathrm{E}$ & $\mathrm{C}$ & $\mathrm{E}$ & $\mathrm{C}$ & $\mathrm{E}$ & $\mathrm{C}$ & $\mathrm{E}$ \\
\hline $\begin{array}{l}\text { Total fibrino- } \\
\text { lytic activity } \\
(\mathrm{E} 440 / \mathrm{h} \times \mathrm{g})\end{array}$ & $\begin{array}{c}40,48 \pm \\
1,56\end{array}$ & $\begin{array}{c}55,80 \pm \\
1,48\end{array}$ & $\begin{array}{c}82,60 \pm \\
1,024 \\
* * *\end{array}$ & $\begin{array}{c}43,04 \pm \\
1,99\end{array}$ & $\begin{array}{c}86,64 \pm \\
1,12 \\
* * *\end{array}$ & $\begin{array}{c}48,76 \pm \\
1,97\end{array}$ & $\begin{array}{c}80,32 \pm \\
1,12 \\
* * *\end{array}$ & $\begin{array}{c}45,52 \pm \\
2,19\end{array}$ & $\begin{array}{c}83,44 \pm \\
1,34 \\
* * *\end{array}$ \\
\hline $\begin{array}{l}\text { Nonenzymatic } \\
\text { fibrinolytic ac- } \\
\text { tivity } \\
(\mathrm{E} 440 / \mathrm{h} \times \mathrm{g})\end{array}$ & $\begin{array}{c}21,20 \pm \\
1,079\end{array}$ & $\begin{array}{c}28,80 \pm \\
1,29\end{array}$ & $\begin{array}{c}44,36 \pm \\
0,995 \\
* * *\end{array}$ & $\begin{array}{c}22,32 \pm \\
1,64\end{array}$ & $\begin{array}{c}45,04 \pm \\
1,072 \\
* * *\end{array}$ & $\begin{array}{c}24,40 \pm \\
1,035\end{array}$ & $\begin{array}{c}40,16 \pm \\
0,54 \\
* * *\end{array}$ & $\begin{array}{c}21,96 \pm \\
1,19\end{array}$ & $\begin{array}{l}40,40 \pm \\
0,95 \\
* * *\end{array}$ \\
\hline $\begin{array}{l}\text { Enzymatic fi- } \\
\text { brinolytic ac- } \\
\text { tivity } \\
(\mathrm{E} 440 / \mathrm{h} \times \mathrm{g})\end{array}$ & $\begin{array}{c}19,28 \pm \\
0,64\end{array}$ & $\begin{array}{c}27,00 \pm \\
0,43\end{array}$ & $\begin{array}{c}38,24 \pm \\
0,508 \\
* * *\end{array}$ & $\begin{array}{c}20,72 \pm \\
0,49\end{array}$ & $\begin{array}{c}41,60 \pm \\
0,32 \\
* * *\end{array}$ & $\begin{array}{c}24,36 \pm \\
0,94\end{array}$ & $\begin{array}{c}40,16 \pm \\
0,58 \\
* * *\end{array}$ & $\begin{array}{c}23,56 \pm \\
1,007\end{array}$ & $\begin{array}{c}43,04 \pm \\
0,57 \\
* * *\end{array}$ \\
\hline
\end{tabular}

Notes: $C$-control; $E$ - experiment; $*-P<0,05 ; * *-P<0,01 ; * * *-P<0,001-$ statistical reliable distinctions 
activity are also contributes to the intensified lysis of fibrin in the junction area at the expense of a direct enzymatic action [10].

At this period of observation in the animals with IIS there occurs a proved rise of TFA into serous layer of intestinal wall, both at the expense of NFA and EFA $(p<0,001)($ table 2$)$

As it is generally known, an activation of the nonenzymatic fibrinolysis is a counterbalance of a stress reaction [11]. The formation of the adrenaline-heparin-antithrombin III complex, activating plasminogen, contributing to its transformation into plasmin and splitting of fibrin, underlies it. However, such an impetuous and pronounced activation of fibrinolysis in the region of the connection may bring about a disturbance of the primary biological leak resistance of the suture line, infecting the thread canal and a penetration of microorganisms out of the intestinal lumen on their surface.

When analysing the histological sections of the anastomotic area of the experimental group of animals it has been revealed more intense neutrophilic infiltration in the submucosal layer of the intestinal wall extending to muscle and serous membranes, also expressed venous plethora and hemorrhages into serous membrane. On contrary the animals of control group the fibrinous mesh into channel of the thread and between the serous membranes was not observed. The formation of loose adhesions with the participation of infiltrated hyperemic tissues of the omentum, the loops of the small intestine and the adjacent loops of the large intestine constituted visual manifestations of primary biological leakage of a junction zone in all the animals of the experimental group during this period.

During a later period (48-72 h.) we observed a tendency to rise of the indices of tissue proteolysis, especially indices of $\mathrm{ACg}$ lysis, which were one and a half time higher than data of the control group. The long increased degradation of collagen molecules in tissues of the junction zone on the conditions of insufficient blood supply may be one of the mechanisms of disturbance of regeneration of sutured tissues [10]. An elevation of the tissue fibrinolytic activity was detected in the animals with IIS, largely at the expense of EFA which exceeded twice the control data. Such an excessive activation of the tissues fibrinol- ysis at the expense of lysis of the fibrin matrix may cause a disturbance of the fixation of fibroblasts in the tissues of the connection area and its regeneration $[8,9]$.

The histological signs of regeneration disturbances in this period of observation were significant diastasis between the serous membranes of intestine touching only in the area of the connected edges of the mucous membrane, also the diffuse inflammatory reaction with expressed neutrophilic and plazmocytic infiltration, edema, plethora and hemorrhages which spread to all layers of intestinal wall. The constant signs of tissues necrosis with the advantage of disintegrated neutrophilic granulocytes and lymphoid cells over macrophages and single active fibroblasts were reveal around canal of the thread. Thus, prolonged intense degradation of collagen molecules in the submucous layer of the intestinal wall, which provides the basic strength of anastomoses may be one of the mechanisms of disturbances of regeneration of sutured tissues in conditions of insufficient blood circulation. Along with it, excessive activation of tissue fibrinolysis due to fibrin matrix lysis can lead to a violation of fixation of fibroblasts in the tissues of the anastomotic area and its insufficient healing.

Conclusions. In case of intestinal sutures insufficiency a specific differently directed changes of proteolityc and fibrinolytic activities are observed in the tissues of the junction area. In the early terms (12-24 h.) an increased level of proteolytic and nonenzymatic fibrinolytic activity of the serous layer of intestinal wall may be one of the mechanisms of disturbance of the primary (biological) leak-resistance of the suture line. At a later stage (24-72 h.) excessive activation of enzymatic fibrinolysis and collagen degradation with hystological signs of excessive neutrophilic and plasma cells infiltration, venous plethora, hemorrage extending to all layers of intestinal wall may contribute in a disturbance of regeneration of the connection region with the onset of sutures insufficiency.

Prospects of further research. On the basis of the last one, we consider it expedient to study correlations between the biochemical changes and degree of microbial contamination of the region of the interintestinal connection at the conditions of sutures insufficiency for the further research.

\section{References}

1. Daams F, Luyer M, Lange JF. Colorectal anastomotic leakage: Aspects of prevention, detection and treatment. World J Gastroenterol. 2013;19(15):2293-7. doi: 10.3748/wjg.v19.i15.2293

2. Sajid MS, Craciunas L, Baig MK. Systematic review and meta-analysis of published, randomized, controlled trials comparing suture anastomosis to stapled anastomosis for ileostomy closure. Tech. Coloproctol. 2013;17(6):631-9. doi: 10.1007/s10151-013-1027-6. Epub 2013 May 17.

3. Boyko V, Markevich V, Lohachov V. Prevention of intraperitoneal complications during operations on the gastrointestinal tract. Surgery Eastern Europe. 2014;1(9):121-9. (in Russian).

4. Riabyi SI. Some pathogenic aspects of intestinal sutures insufficiency. Clinical and experimental pathology. 2013;3:154-7. (in Ukrainian).

5. Mehlnyk VM, Poyda OI. Surgical tactics in insufficiency of the interintestinal anastomoses sutures. Clin Surg. 2016;6:8-12. (in Ukrainian).

6. Vasiliu EC, Zarnescu NO, Costea R, Neagu S. Review of Risk Factors for Anastomotic Leakage in Colorectal 
Surgery. Chirurgia (Bucur). 2015;110(4):319-26.

7. Guyton KL, Hyman NH, Alverdy JC. Prevention of Perioperative Anastomotic Healing Complications: Anastomotic Stricture and Anastomotic Leak. Adv Surg. 2016;50(1):129-41. doi: 10.1016/j.yasu.2016.03.011. 8. van der Wal JB, Jeekel J. Biology of the peritoneum in normal homeostasis and after surgical trauma. Colorectal Dis. 2007;Oct;9 Suppl 2:9-13. doi:10.1111/j.1463-1318.2007.01345.x.

9. Arung W, Meurisse M, Detry O. Pathophysiology and prevention of postoperative peritoneal adhesions. World J Gastroenterol. 2011;Nov 7;17(41):4545-53. doi: 10.3748/wjg.v17.i41.4545

10. Chondrogianni N, Petropoulos I, Grimm S, Georgila K, Catalgol B, Friguet B, et al. Protein damage, repair and proteolysis. Mol Aspects Med. 2014 Feb;35:1-71. doi: 10.1016/j.mam.2012.09.001.

11. Litvinov RI. Molecular mechanisms and clinical significance of fibrinolysis. Kazan Medical Journal. 2013;94(5):711-8. (in Russian).

\section{ЗНАЧЕНИЕ ПРОТЕОЛИТИЧЕСКОЙ АКТИВНОСТИ ТКАНЕЙ КИШЕЧНОЙ СТЕНКИ ДЛЯ ЗАЖИВЛЕНИЯ ЗОНЫ СОЕДИНЕНИЯ В УСЛОВИЯХ РАЗВИТИЯ НЕСОСТОЯТЕЛЬНОСТИ АНАСТОМОЗОВ}

Резюме. Цель исследования - изучить влияние специфических изменений протеолитической и фибринолитической активностей тканей кишки непосредственно в области соединения на регенераторные свойства анастомозов в условиях развития их несостоятельности. Методы. На модели несостоятельности кишечных швов в 72 экспериментальных животных исследованы изменения показателей протеолиза, суммарной, неферментативной и ферментативной фибринолитической активности соединенных тканей кишечника. Результаты. Установлено, что повышенная фибринолитическая и протеолитическая активность тканей кишечника может быть одним из механизмов нарушения первичной (биологической) герметичности линии швов в ранние сроки (12-24 ч.). В более поздние сроки (24-72 ч.) чрезмерная активация ферментативного фибринолиза и деградации коллагена сочеталась с гистологическими признаками избыточного нейтрофильной и плазмоцитарной инфильтрации, венозного полнокровие и кровоизлияния, которые распространялись на все слои кишечной стенки. Такая комбинация рост деструктивных процессов с истощением систем защиты может быть в основе нарушения регенерации зоны соединения с возникновением несостоятельности швов.

Ключевые слова: протеолиз; фибринолиз; регенерация; несостоятельность кишечных швов; эксперимент.

\section{THE SIGNIFICANCE OF PROTEOLYTIC ACTIVITY OF INTESTINAL WALL TISSUES FOR THE SUTURED AREA HEALING UNDER THE CONDITIONS OF ANASTOMOTIC LEAK-AGE DEVELOPMENT}

Abstract. The mortality rate after formation of colorectal anastomosis is up to $22 \%$. The unsatisfacto-ry results of treatment of this polyethiological com-plication are largely associated with an insuffi-cient study of all its pathogenetic aspects. In existent researches a great attention deals to study and modifi-cation the risk factors of anastomotic leakage, such as nutrition disturbances, smoking, steroids and chemotherapy, duration of surgical treatment, volume of infusion and blood transfu-sion etc. The aim of research - to study influence of specific changes of proteolytic and fibrinolytic activities of intesti-nal tissues directly into the region of sutures on regenerative properties of anastomosis under condi-tions of their leakage development. The experiments have been carried out on 72 albino nonlinear male rats, weighting $180 \pm 20 \mathrm{~g}$. ISI was modelled by way of excessive mobilization of the area of junc-tion and a rare application of stitches in the animals of the experimental group. Methods. The changes of indices of proteolysis, total (TFA), nonenzymatic (NFA) and enzymatic (EFA) fibrinolytic activities into sutured tissues of bowel were researched on model of intestinal sutures insufficiency in 72 exper-imental animals. Results. It was detected that increased fibrinolytic and proteolytic activity may be one of the mechanisms of disturbance of the primary (biological) leak-resistance of the suture line in the early (12-24 h.) terms. At a later stage (24-72 h.) excessive activation of enzymatic fibrinolysis and collagen degradation was combined with hystological signs of excessive neutrophilic and plasma cells infiltration, venous plethora, hemorrage extending to all layers of intestinal wall. Such combination of rising of destructive processes with the depletion of protective systems may contribute in a disturbance of regeneration of the connection area with the onset of sutures insufficiency.

Key words: proteolysis, fibrinolysis, regeneration, anastomotic leak, experiment.

Відомості про авторів:

Рябий Сергій Ілліч - кандидат медичних наук, асистент кафедри догляду за хворими та вищої медсестринської освіти ВДНЗ України «Буковинський державний медичний університет», м. Чернівці.

Information about the authors:

Riabyi Sergii I. - Candidate of Medical Sciences, Assistant of the Department of Patient Care and Higher Nursing Education HSEI of Ukraine «Bukovinian State Medical University», Chernivtsi.

Надійшла 11.04.2019 p. Рецензент - проф. Сидорчук Р.І. (Чернівці) 